\title{
THE DESIRE FOR WHITENESS: CAN LAW AND ECONOMICS EXPLAIN IT?
}

\section{SHILPI BHATTACHARYA*}

This Article provides a new theoretical perspective on colorism by considering it from an economic point of view. It relies on three theories of law and economics that explain racism. While critiquing these theories, it also extends them to evaluate colorism. Because these theories correlate race with skin color, applying these theories to colorism requires distinguishing colorism from racism using the "desire for whiteness" as a tool for analysis. Further, this Article provides a comparative perspective of colorism in the traditional American labor market and the Indian arranged marriage "market." It finds that: (a) these theories are able to provide some insight into why decisions in these markets are colorist; (b) the insights are incomplete and do not fully explain the complexities of colorist interactions, though they do explain some of colorism's history; (c) the Indian arranged marriage market strengthens these theories; and (d) only McAdams's status production theory is able to deliver an account of the desire for whiteness. It concludes that a legal framework relating to colorism should aim to eliminate this desire from society.

\section{INTRODUCTION}

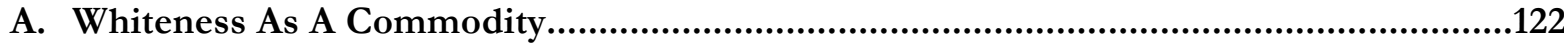

II. Aligning Colorism with Racism.................................................................................125

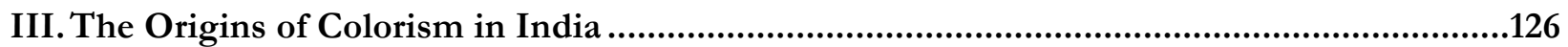

A. A Historical View of Colorism in Arranged Marriages in India.....................................128

IV. FITTING COLORISM IN A THEORETICAL FRAMEWORK...................................130

Assistant Professor of Law, O.P. Jindal Global University, Delhi, India. B.A., LL.B. (Honors), The WB National University of Juridical Sciences; LL.M. University of Virginia School of Law. I would like to thank Richard McAdams, Lee Fennell, Prabhakar Singh, Sudha Bhattacharya, Alok Bhattacharya and the participants and panelists at the 2011 Law in Society Annual Conference in San Francisco for extremely helpful comments and suggestions. I would also like to express my deep gratitude to the Editors of this journal for their contribution towards shaping this article. The usual caveat applies. 


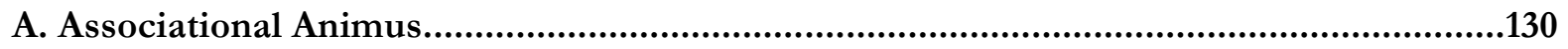

1. Does Becker's theory explain colorism?....................................................................132

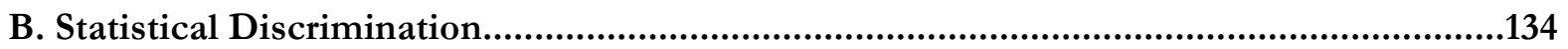

C. Can statistical discrimination explain colorism?...........................................................137

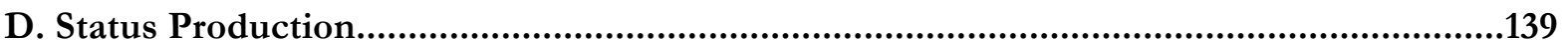

E. How does status production explain free riding?.......................................................140

F. Applying the theory of status production.....................................................................142

G. Can the status production theory also explain colorism?...............................................144

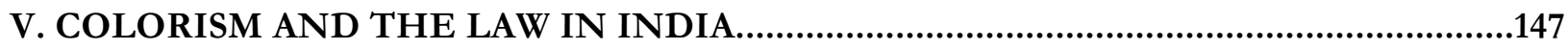

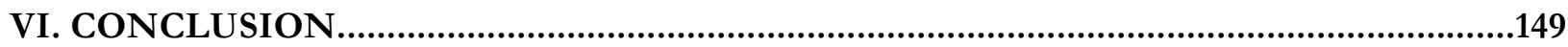

\section{INTRODUCTION}

She's more like a gypsy nor ever," said aunt Pullet, in a pitying tone; "It's very bad luck, sister, as the gell should be so brown; the boy's fair enough. I doubt it'll stand in ber way i' life to be so brown. - George Eliot 1

Aunt Pullet's concern for the future of Maggie Sullivan, the so-called "brown-skinned"2 heroine of George Eliot's classic novel The Mill on the Floss, was not unfounded. ${ }^{3}$ Studies have shown that colorism, the differential treatment of individuals in economic and social transactions based solely on differences in skin color, is pervasive in modern societies. Expressed positively, colorism is a preference for persons of lighter skin; expressed negatively, it is the exclusion, denial, or penalizing of persons of darker skin.

This Article introduces colorism to the law and economics discussion of racism, and considers whether the existing theories of discrimination in law and economics provide an explanation for colorism. This Article finds that existing theories of racism are unable to explain the deep rootedness or persistence of colorism. Yet these theories allow for a better understanding of the complexities of colorism and its relationship to racism. More importantly, the insights provided by the application of these theories are useful in locating the role of law in addressing colorism.

${ }^{1}$ George Eliot, The Mill on the Floss 58 (S. Shuttleworth ed., Routledge 1991) (1860).

2 Brown-skinned people_-those who are neither black nor white, but fall in between-are the easiest to identify as the targets of colorism.

${ }^{3}$ See ELIOT, supra note 1 (George Eliot portrayed Maggie Sullivan, the dark-skinned protagonist of The Mill on the Floss as a tragic and non-conformist heroine. Her dark color and her family's lamentations and chidings about her skin color were integral parts of the tragic atmosphere of the strife, struggle, and confrontation that Eliot built around Maggie's character. It was considered unusual for the heroines of romantic novels at that time to be portrayed as darkskinned). 
Colorism is intuitively linked to racism because skin color has dominated our understanding of racial classifications. In societies that are racially heterogeneous such as the United States, skin color preferences may be more commonly tagged as racism, whereas similar preferences may be classified as colorism in societies that are racially uniform. Can the same behavior constitute racism in one society and colorism in another? Comparing racially homogenous and heterogeneous societies such as India and the United States, respectively, can provide a more comprehensive understanding of the source and existence of colorism and its distinction from racism. This Article undertakes such a comparative study by examining the prevalence of colorism in the United States employment market and the Indian "arranged marriage market." 4 This provides the opportunity to study colorism in the public and private spheres in different cultural contexts. In this way, the economic theories of racism are truly challenged in their application to such completely contrasting circumstances, and in the process, their strengths and weaknesses are better exposed.

Colorism is expressed in many nations as a desire for whiteness. Why do people of nearly all races have a desire for whiteness? The answer will enable a better understanding of how law can address colorism.

This Article examines three existing economic theories of racism. Gary Becker introduced the first economic theory based on taste for discrimination. ${ }^{5}$ Second is the theory of statistical discrimination. ${ }^{6}$ Statistical discrimination occurs when generally held beliefs about average group characteristics are used to make assumptions about the behavior of individual members of the group. ${ }^{7}$ The third and most recent account of racial discrimination is Richard McAdams's status production theory. ${ }^{8}$ Race discrimination by this account is "a means by which people who share roughly similar but observable traits that come to be known as "race' produce social status for themselves." 9 The commonality of these theories is that they rely on the visibility of skin color and the ease with which skin color allows us to make racial classifications.

This Article is divided into six parts. Part I argues that the existence of colorism is established through the prevalence and pervasiveness of whiteness as a privilege in society. Part II examines whether it is possible to distinguish between colorism and racism. Part III studies some aspects of the history of colorism in India. Part IV examines the economic theories of racism and attempts to relate them to colorism. Part V discusses the law on colorism in India. Part VI puts forward a conclusion.

${ }^{4}$ Most marriages in India are arranged. This means that the marriage is initiated and determined by one or more intermediaries, usually a family member, rather than the prospective marriage partners themselves.

5 See Gary Becker, The Economics of Discrimination 14 (2d ed. 1971).

${ }^{6}$ Edmund Phelps and Kenneth Arrow have been credited with introducing this theory. Economists Dennis Aigner, Glen Cain, Shelly Lundberg, and Richard Startz later contributed to the theory. This Article limits itself to the initial theorization of statistical discrimination by Phelps and Arrow.

${ }^{7}$ Stewart Schwab, Is Statistical Discrimination Efficient?, 76 AM. ECON. REV. 228 (1986).

${ }^{8}$ Richard H. McAdams, Co-operation and Conflict: The Economics of Group Status Production and Race Discrimination, 108 HARV. L. REV. 1003 (1995).

${ }^{9}$ Id. at 1045 . 


\section{A. Whiteness As A Commodity}

Cheryl Harris describes whiteness as a kind of property, evidenced, for instance, by the attempts of blacks with light skin color to "pass" as white. As she explains it, blacks attempted to pass as white because possessing whiteness meant enjoying various privileges that were exclusively associated with being white. ${ }^{10}$ Colonization and the slave trade led to the legal construction of blacks as chattel. The exploitation of black slaves contributed to the construction of whiteness as property because, at that time, whiteness represented mastership. ${ }^{11}$ Therefore, being white was valued in a manner similar to the value associated with the possession of property. In America, the law played a significant role in creating and sustaining the idea of whiteness as property by recognizing the differential rights and privileges of whites. ${ }^{12}$ Similarly, whiteness was valued in colonial India because whites had privileges that native Indians did not. ${ }^{13}$ In short, whiteness had value. It was exclusively possessed and, therefore, it was desired.

In what way do we value whiteness and how do we measure its value to us? ${ }^{14}$ Is the value given by individuals to whiteness a factor of the racial identity of that individual? Studies have shown that skin tone has a substantial impact on the way a person is treated in society and affects one's chances for successful employment and marriage. ${ }^{15}$ In many societies, skin color is directly associated with social status, and those who are dark-skinned are economically and socially disadvantaged. ${ }^{16}$ In America, lighter-skinned blacks are reported to face much lower incidences of discrimination than darker-skinned blacks, not only from whites but also from other blacks. ${ }^{17}$ The literature shows similar effects for darker-

${ }^{10}$ Cheryl I. Harris, Whiteness as Property, 106 HARV. L. REV. 1709, 1713 (1993).

${ }^{11} I d$. at $1715-16,1721$.

12 Id. at $1737-42,1745$.

13 An example of this is exclusive membership in clubs and other social institutions. See, e.g., Mrinalini Sinha, Britishness, Clubbability, and the Colonial Public Sphere: The Genealogy of an Imperial Institution in Colonial India, 40 J. BRIT. STUD. 489, 490 (2001).

14 Andrew Hacker, Two Nations, Black and white, Separate, Hostile, Unequal (1992) (describing a study conducted on a group of white students to determine how much they valued whiteness that asked each student how much financial recompense they would request to be changed from white to black; many students asked for $\$ 50$ million or $\$ 1$ million for each black year).

15 Research conducted before and during the Civil Rights Movement suggested a continuing relationship between the variations in skin tone and the life opportunities of black Americans. The study finds strong support for continuing social stratification of blacks on the basis of skin tone. See Verna M. Keith \& Cedric Herring, Skin Tone and Stratification in the Black Community, 97 AM. J. Soc. 760, 760-61 (1991). Darkness is found to lead to greater criminal activity, suggesting that darker blacks face greater disadvantages in legitimate opportunities, and as a result are driven to criminal activity. See, e.g., Kwabena Gyimah-Brempong \& Gregory N. Price, Crime and Punishment: And Skin Hue Too?, 96 Am. ECON. REV. 246 (2006); see also Leonard M. Baynes, If It's Not Just Black and White Anymore, Why Does Darkness Cast a Longer Discriminatory Shadow Than Lightness? An Investigation and Analysis of the Color Hierarchy, 75 DENV. U. L. REV. 131 (1997) (discussing various studies which establish that darker-skinned persons face greater discrimination than lighterskinned persons).

16 See William A. Darity, Jr., Intergroup Disparity: Economic Theory and Social Science Evidence, 64 S. ECON. J. 805, 821 (1998) (citing studies conducted in different countries that uniformly evidence social and economic preference for lightskinned persons).

17 Blacks with lighter skin tone report dramatically better treatment from whites and partially better treatment from blacks than those with darker skin tone. See Joni Hersch, Skin Tone Effects Among African Americans: Perceptions and 
skinned persons of other racial categories as well, such as Asians and Latinos. ${ }^{18}$ In China, there is a common saying that "white skin can cover 1,000 uglinesses."19

In India, there is an entrenched social preference for white skin. ${ }^{20}$ Lighter skin is considered a sign of beauty and men specifically seek light skin color as a requirement in a prospective mate. ${ }^{21}$ Fairness cream advertisements connect fairness to greater employability and beauty. ${ }^{22}$ Initially, these products catered specifically to women, ${ }^{23}$ but recently, a large number of these fairness creams have started being marketed for men. ${ }^{24}$ Some fairness creams include "shade meters" that measure skin tone before and after using the product. This is a clear instance of the social legitimization of the desire for whiteness and its commodification by the encouragement of whiteness as an ideal that can be attained by gradually moving from a darker to a lighter shade.

Reality, 96 Am. ECON. REV. 251 (2006). Alice Walker defined the "prejudicial or preferential treatment of same race people based solely on their skin color" as "colorism." See AliCE WALKer, If the Present Looks Like the Past, What Does the Future Look Like?, in In SEARCH OF OUR Mothers' GARDENS 290, 290-91 (1983); see also Trina Jones, Shades of Brown: The Law of Skin Color, 49 DUKE L.J. 1487 (2000) (discussing the history and evolution of colorism, its role in present society, and the treatment of courts regarding claims of colorism).

18 See Kajalie Shehreen Islam et. al., Fair Factor: The Whiter the Better, STAR WeEKEnd MAGAZINE (May 12, 2006), available at http://www.thedailystar.net/magazine/2006/05/02/cover.htm (preferences for lighter skinned women amongst Bangladeshi men and the lengths to which Bangladeshi women go to lighten the color of their skin by a few shades in a society where everyone is a shade of brown). Discrimination based on darkness of skin is not limited to African Americans. See Baynes, supra note 15, at 131. The wages of Latino men tend to decrease with the darkness of their skin. See Christina Gomez, The Continual Significance of Skin Color: An Exploratory Study of Latinos in the Northeast, 22 HiSP. J. BEHAV. SCI. 94, 94 (2000).

19 Pearl E. Grimes, Aesthetics And Cosmetic Surgery for Darker Skin Types 12 (2008).

20 See Debarshi Dasgupta, Our True Colours, OuTLook (July 29, 2009), http: / / outlookindia.com / fullprint.asp?choice $=1 \&$ fodname $=20090629 \&$ fname $=$ Cover + Story $+\% 28 \mathrm{~F} \% 29 \& \operatorname{sid}=1$

(describing Indians' obsession with skin color, including the lower adoption numbers for darker babies in adoption agencies, and an incident in which a woman committed suicide after her husband constantly harassed her for being dark).

21 See William Darity, Jr., Caste or Race: Parallels or Disjunctions, in Against Stigma: Studies in CaSte, Race AND Justice SinCE Durban 400 (Balmurli Natrajan \& Paul Greenough eds., 2009) (in a national survey taken in 2000 by the Family Planning Commission of India of 3,800 young people, sixty-seven percent said they would look for a "fair complexion" in a prospective mate, citing Malvika Kaul, Arranged Marriages Bounce Back: What's Love Got To Do With It, THE Sunday Times OF INDiA REV. (Sept. 3, 2000)). However, Darity points out that "the real test for the presence of a racial system in India would be that color is associated strongly with social status and economic privilege." Darity, supra note 16 .

${ }^{22}$ For instance, an Indian whitening cream television advertisement depicts a dark complexioned woman being rejected for a job at a beauty company and then after using the cream and becoming a few shades lighter she is shown to not only be given the job but a leading position at the beauty company. See fuffu2009, Fair $n$ Lovely Ad India Female, YouTuBE, July 23, 2009, http://www.youtube.com/watch?v=ubbufbkbovY (Ayurvedic Fair and Lovely Skin Cream by Hindustan Unilever Ltd.).

23 Prior to the advent of whitening creams, traditional remedies were used for skin lightening.

${ }^{24}$ For examples of these products, see Emami Fair and Handsome: Advanced Whitening Cream for Men by Emami, available at http://www.fairandhandsome.ae/ (last visited Feb. 5, 2012), and Fair and Lovely Maximum Fairness (Fairness Cream for Men) by Hindustan Unilever Ltd., available at http://www.fairandlovely.in/products/men.aspx (last visited Feb. 5, 2012). Nivea for Men has a range of skin whitening products by Beiersdorf, available at http://www.niveaformen.in/products/whitening.html (last visited Feb. 5, 2012). 
The desirability of whiteness is also reflected in mainstream cinema. Black women rarely play romantic leads in Hollywood films and those that do are usually lighter complexioned. ${ }^{25}$ Similarly, almost all Indian women who play romantic roles in Bollywood films are also light-skinned. ${ }^{26}$

Thus, both Western and Eastern societies attach a similar value to whiteness. Just as Trina Jones recounts experiences of warnings given to black women against staying out for long periods in the sun for fear of becoming too dark, ${ }^{27}$ Indian girls are also brought up with similar warnings and associated negative conceptions surrounding dark skin color.

Darker-skinned people use skin lightening creams and other products to increase their access to opportunities and resources. ${ }^{28}$ Whiteness is thus an asset-a property that has crossed cultural differences to come to be universally valued and commodified. Those who possess it are privileged and those who do not constantly seek to acquire it in the hope of overcoming their disadvantage. ${ }^{29}$

Dark-skinned people have not sufficiently questioned the value attached to whiteness. They have accepted white standards of beauty and value as true. Because of this, a desire for whiteness has developed among them and they are also prejudiced along similar lines..$^{30}$

The preceding discussion suggests that colorism is expressed as a preference for whiteness. However, is the desire for whiteness merely a form of racism or is it its own independent phenomena? The following section examines the distinction between racism and colorism.

25 Jones, supra note 17 , at 1514 .

${ }^{26}$ Dark complexioned Indian women actors such as Nandita Das and Smita Patil have been restricted to roles in alternative cinema rather than mainstream Bollywood. See Zeenat Khan, Kennedy Centre Honors Indian Women in Film, INDEP., March 23, 2011, http://www.theindependentbd.com/paper-edition/editorial/post-editorial/40497-kennedycentre-honours-indian-women-in-film.html (Nandita Das admits that skin color affects the kind of roles a woman can get in films); see also Evelyn Nakano Glenn, Yearning for Lightness: Transnational Circuits in the Marketing and Consumption of Skin Lighteners, 22 GEND. \& SOC’Y 281, 290 (2008).

${ }^{27}$ Jones, supra note 17 , at 1520 n.145.

28 According to a Villanova University study, another example of the benefit of lighter skin color is that lighterskinned women are more likely to receive shorter prison sentences than darker-skinned women. See Bim Adewunmi, Racism and Skin Color: The Many Shades of Prejudice, GuARDIAN, October 4, 2011, http://www.guardian.co.uk/world/2011/oct/04/racism-skin-colour-shades-prejudice?INTCMP=SRCH.

29 The belief in the advantages of lighter skin color is ingrained at a young age. See DARK GIRLS (Urban Winter Entertainment; Duke Media 2011) (The preview of the documentary film DARK GIRLS shows a clip from a 2010 pilot study in which schoolchildren were asked to select from pictures of dolls ranging from light to dark. The researcher asks a five-year-old black girl to show her the smart child. The girl points to the image of the lightest child. She does the same when the researcher asks her to pick the good-looking child. Her reasons are "because she's white" and "because she's light-skinned." By contrast, she selects the darkest child when asked to pick out the "ugly" child and the "dumb" child. This time, her reason is "cause she's black").

30 Glenn, supra note 26, at 289; see also Cynthia E. Nance, Colorable Claims: The Continuing Significance of Color Under Title VII Forty Years After Its Passage, 26 Berkeley J. EMP. \& LAB. L. 435, 441 (2005); DARK GIRLS (Urban Winter Entertainment; Duke Media 2011). The preview for the documentary film shows how the African American community has accepted lighter skin color as the prevailing standard of beauty. 


\section{ALIGNING COLORISM WITH RACISM}

Existing scholarship on colorism has distinguished colorism from racism in order to establish the presence of colorism as a distinct phenomenon. ${ }^{31}$ For instance, Jones believes that while colorism is an important element of racism, it is also its own distinct phenomenon. ${ }^{32}$ Title VII of the Civil Rights Act of 1964 distinguishes color from race as grounds for a claim of discrimination. ${ }^{33}$

The obvious ground for distinction between the two is that colorism is not confined to the technicalities of racial boundaries, i.e. it can be both inter-racial and intra-racial. For instance, Aunt Pullet's concern in The Mill on the Floss was that the protagonist Maggie Sullivan's brown skin would not be considered favorably by prospective white suitors even though she was racially white. ${ }^{34}$ This represents intra-racial colorism.

Particularly in the context of racially homogeneous societies, it is worth questioning whether the distinction between colorism and racism is a genuine one to make. Scholars have argued that there is a more fundamental basis for this distinction, which derives from a critical conception of race and the construction of racial boundaries. According to Jones, skin color is the device used to assign racial categories to people and race is the social treatment that is given as a result of that categorization. ${ }^{35}$ Consequently, differences in treatment based on skin color do not result from racial categorization per se but from difference in skin color alone. ${ }^{36}$ As a corollary, the value associated with being lighter- or darker-skinned is related to the proximity of skin tone to the racial ideal, i.e. white. ${ }^{37}$

Is the desire for whiteness a reflection of racism or colorism? Vijay Prashad argues that the desire for whiteness cannot be conflated with race because conceptions of beauty are to do with the quality and not the essence of being. ${ }^{38}$ Such conflation, Prashad argues, "does not enable us to grasp the historical dynamics of skin color on the subcontinent." 39 The consumption of products, such as skin lightening creams, that are designed to shift color boundaries nevertheless cannot change racial categories. Similarly, a changing color dynamic, such as a move towards a preference for light but not absolutely white skin colors, ${ }^{40}$ will not affect conceptions of race.

31 See Jones, supra note 17, at 1493-98; see also Angela P. Harris, Economies of Color, in SHADES OF DIFFERENCE: Why SKIn COLOR MATTERS 1, 1-5 (Evelyn Nakano Glenn ed., 2009).

32 See Jones, supra note 17, at 1493-99.

33 Under Title VII, courts in the United States can recognize colorism as a distinct harm. However, there have been few discrimination claims based solely on color, and many of the cases alleging color discrimination also allege race discrimination. See Nance, supra note 30, at 436.

34 See ELIOT, supra note 1, at 125.

35 See Jones, supra note 17, at 1493-98.

${ }^{36}$ Id. at $1493-98$.

${ }^{37}$ Jones, supra note 17 , at 1498 n.31.

38 Vijay Prashad, The Karma of Brown FolK 98 (2000).

${ }^{39} I d$.

40 See Harris, supra note 31, at 4. 
Colorism questions the clarity with which people are grouped into racial categories through skin color and therefore questions the basis on which individuals are assigned racial categories. ${ }^{41}$ Some scholars consider colorism as a complex aspect of race discrimination. ${ }^{42}$ Scholars holding this view consider colorism to be an evolutionary product of racism that will replace it, rather than a parallel and distinct phenomenon that coexists with racism. Colorism is viewed as a consequence of the increasing intermixing of races, resulting in the blurring of clearly defined racial categories as black and white, and the replacement of racism. Colorism then becomes the basis for subordination and discrimination among people of color. ${ }^{43}$

The following discussion describes the origins of colorism in India and historicizes the importance of skin color in the practice of arranging marriages in India. ${ }^{4}$

\section{THE ORIGINS OF COLORISM IN INDIA}

It is helpful to understand the origins of colorism in India in order to comprehend its nature and its connection to the institution of arranged marriage. Skin color was considered important in India from a very early time, possibly dating as far back as 1500 B.C., when the Aryans were said to have invaded India. The British colonization of India actually served to reinforce the conceptions of skin color that already existed. 45 If colorism was not a product of colonization, can it be argued that its origin was independent of race? It is reasonable to assume that a variety of influences from India's vibrant history all contributed in some way to the modern Indians' attitudes towards skin color. Yet as the discussion below shows, early conceptions of color played an important role in setting the stage for modern attitudes towards colorism. This includes skin color preferences in arranged marriages. Light skin color is a crucial aspect of appearance and is an important factor in selecting a partner in an arranged marriage. 46 It is argued that both the origins of colorism and its role in Indian arranged marriages were connected to early forms of the caste system in India. While early caste classifications may have been connected in some way to race, they were never completely superimposable. Thus, unlike in the United States, colorism in India was never clearly a product of racial classifications. This will be discussed in greater detail in the discussion that follows.

41 See id. at 1-2 ("Colorism and racism are not only not identical; hierarchies of color can destabilize hierarchies based on race ... [C]olorism operates sometimes to confound and sometimes to restructure racial hierarchy.”).

42 See, e.g., Baynes, supra note 15, at 131 (defining racism by a darkness and lightness paradigm); Taunya Lovell Banks, Colorism: A Darker Shade of Pale, 47 UCLA L. REV. 1705 (2000) (arguing that skin tone discrimination is a form of race discrimination).

43 See Jones, supra note 17, at 1524; Baynes, supra note 15, at 133 (arguing that even if race itself does not matter, color will still be a source of discrimination).

${ }^{44}$ For an interesting description of the process of selecting a prospective bride in an Indian arranged marriage, see Serena Nanda, Arranging a Marriage in India, in Stumbling Towards TruTH: Anthropologists AT Work 196204 (Philip R. Devita ed., 2000).

45 See Jyotsna Vaid, Fair Enough?: Color and the Commodification of Self in Indian Matrimonials, in SHADES OF DifFERENCE: Why SkIN Color MATTERs 149 (Evelyn Nakano Glenn ed., 2009). Glenn believes that there is no evidence of colorism in Vedic texts, but the association between skin color and social status likely predates British rule. See also PRASHAD, supra note 38, at 97 (stating that existing notions of whiteness aligned with racist European notions).

46 Vaid, supra note 45, at 148. 
There are some peripheral indications of colorism in Vedic India. ${ }^{47}$ For instance, the division of texts in the Yajurvedat8 into the Taittiriya-sambita, also called the Krishna or black Yajurveda, and the Vajasaneyi-sambita, also called Shukla or white Yajurveda because the former is said to be "rather confused" and the latter only contains mantras, points towards associations of white color with superiority and purity in ancient India. ${ }^{49}$ In other words, the imperfect text was known as the "black" text and the pure text was known as the "white" text. The connotations attached to the colors white and black in ancient India may have had some connection with perceptions of skin color at that time.

Further, certain scholars such as Macdonell ${ }^{50}$ have put forth a view that the division of the Indian caste system was based on race rather than occupational distinctions, though this interpretation of the history of the caste system is controversial and has been discredited in some scholarship. ${ }^{51}$ Macdonell argued that the word used in the later Vedas to describe the division of Indian society into different castes is Varna, which some scholars have contended, means "color." 52 According to Macdonell, the three upper castes in India — the priests, the military and the peasantry—-were also collectively designated the Arya Varna, or "Aryan color," and the lower castes were designated the Dasa Varna, or "slave color." 53 This is also expressed in the Rig Veda ${ }^{54}$ by the description "black skin." 55 Macdonell was of the view that the word varna (color) was used to emphasize racial distinctions in these classifications. ${ }^{56}$ Macdonell has argued that later Indian texts also describe the importance of color distinctions in the conception of the caste system. ${ }^{57}$ In certain Pali58 texts, brahmins (members of the highest caste) have been expressed as considering themselves of the white varna and the other castes as of the black varna. ${ }^{9}$ Nehru argues that the caste system served to organize different races that existed in India at the time-

47 This is a period of Indian history that is recorded through texts known as the VEDAS, which provided some of the earliest records of Indian history. The chronology of this period is disputed and some scholars consider it to go as far back as $2500 \mathrm{BC}$ though the more commonly accepted date is 1500 B.C. The four texts constituting the VEDAS were a collection of existing knowledge and philosophy. These texts are credited to the Aryans and their invasion of India. They are now considered as the earliest source of Hinduism. See JAwAHARLAL NeHru, The DisCOVERY OF INDIA 7681 (1946).

48 This is one of the four collections of texts of the VEDAS and contains religious recitations for officiating priests.

49 See Yajurveda 5 (Rajbali Pandey trans., Diamond Pocket Books 2006).

50 A.A. Macdonell, The Early History of Caste, 19 AM. HiST. REV. 230 (1914).

${ }^{51}$ Ralph Pieris, Caste, Ethos, and Social Equilibrium, 30 SOC. FORCES 409, 410 n.12 (1952)

52 Macdonell, supra note 50, at 237.

53 Id. at 241 .

54 This is one of the four collections of texts of the VEDAS and is a collection of hymns.

55 Macdonell, supra note 50, at 241.

56 See id. at 241.

${ }^{57}$ Id. at 243 n.9.

58 A language of North India used at the time of Buddha and associated primarily with Buddhist texts.

${ }^{59}$ Id. at 243 n.9. 
the Aryans, the Dravidians, and the indigenous tribes. ${ }^{60}$ The caste system began as a division between the Aryan and non-Aryan races, and enabled a more peaceful mechanism for the Aryans to enforce their superiority over the conquered population. ${ }^{61}$ The caste system later acquired a more complex character as the division of functions and specializations within the caste system increased. Others, however, argue that division of society under the caste system was based on occupation and not race or skin color, and the claim that the caste system originated from skin color does not reflect the complexities of caste nor the ways in which the caste system subsequently evolved in India. ${ }^{62}$

\section{A. A Historical View of Colorism in Arranged Marriages in India}

The early history of colorism is also interlinked with customs of marriage. Once the Aryans conquered India, they established rules of endogamy. Marriage outside the race or near degrees of kinship was forbidden. ${ }^{63}$ Durant believed that Aryans established these rules of inter-marriage and caste divisions based not on status but on color because they foresaw that, without these rules, their small numbers would be assimilated into the local population and they would lose their racial identity. ${ }^{64}$ Durant also argued that initially the caste system was a system of racial division, its primary purpose being to regulate marriages in an endogamous group. ${ }^{65}$ As Durant described it, it separated long noses from broad ones and Aryans from Dravidians. ${ }^{66}$ Thus, arranged marriages were strictly regulated through the caste system to prevent the intermixing of castes and possibly races.

In later Indian history, the idea of the arranged marriage evolved and became popular for the reasons explained below. Marriage was compulsory in the Hindu system and unmarried men were considered outcasts. ${ }^{67}$ Of marriage, Durant writes:

Nor was marriage to be left to the whim of individual choice or romantic love; it was a vital concern of society and the race, and could not be safely entrusted to the myopia of passion or the accidents of proximity; it must be arranged by the parents before the fever of sex should have time to precipitate a union doomed, in the Hindu view, to disillusionment and bitterness. Manu gave the name of Gandharva marriage to unions by mutual choice, and stigmatized them as born of desire; they were permissible, but hardly respectable. ${ }^{68}$ Manu prescribed eight types of marriage of which the most prevalent and

\footnotetext{
60 See NEHRU, supra note 47, at 84-85.

61 See id. at 85.

62 See S. Chandrasekhar, Caste, Class, and Color in India, 62 SCI. MonTHLY 151, 156 (1946).

63 WiLl Durant, The STORY OF Civilization 398 (1954).

${ }^{64}$ Id. at 398.

${ }^{65} I d$.

${ }^{66} \mathrm{Id}$.

${ }^{67}$ Id. at 489 .

${ }^{68} I d$.
} 
acceptable form was one arranged by the parents which followed the rules of endogamy - marriage within the caste and outside the gotra. ${ }^{69,70}$

Caste, even in the present day, typically serves to restrict marriage in Hindu arranged marriages. ${ }^{71}$ One's marital partner is found from within the same caste. ${ }^{72}$ In the past, the views of the prospective bride and groom were not consulted in the choice of a partner, as the marriage was not considered to be properly a matter of their concern. ${ }^{73}$ However, this practice is increasingly changing in arranged marriages in urban areas. Traditionally, marriages were arranged by elder family members of the bride and groom with the process typically being initiated by the family of the bride. The bride's family looks for a suitable unmarried man from within their own or their extended social circle. ${ }^{74}$ While this practice still exists, it has evolved to account for modern forms of communication such as the Internet and newspapers, where profiles are now advertised. Dependence on immediate social circles as a means to find a partner has reduced. In seeking a partner, the families of the bride and groom will consider a lighter colored girl to be more attractive. ${ }^{75}$ Other attributes considered are age, health and absence of visible infirmities. ${ }^{76}$ Skin color has thus played and continues to play an important role in the Indian arranged marriage process. Arranged marriages served to limit the occurrence of inter-caste unions. However, the history of arranged marriages in India does not explain how skin color preferences have become such an integral part of the process of mate selection. The initial color-based division of the caste system would, on the other hand, explain modern attitudes towards skin color even though the caste system is no longer divided along color lines.

The view presented above of the possibly color-based division of Indian society in ancient times by the then-invading Aryans is similar to the later history of American and of European colonization. This repeated use of whiteness in the historical dynamics of power and exploitation has resulted in a separate value being associated with it. This value disregards racial boundaries. The history of colorism thus points towards a more complex relationship of color and race that has created a value in whiteness. Colorism may no longer be confined to a subset of racism.

69 Along with caste, every Hindu is also assigned a gotra. The nature of the gotra varies regionally. All members of a gotra are claimed to be descendants of a common founding ancestor. The question of gotra membership is only relevant in the present day in determining prospective marriage partners. An arranged marriage will generally not take place between members of the same gotra." DURANT, supra note 63, at 958.

${ }^{70}$ Id. at 492. See also Abu L-FAZL Allami, The A-IN-I-AkBARi (InStituTE OF AKBAR) 337-41 (Sir Jadunath Sarkar ed., H. S. Jarrett trans., Low Price Publications, 1949) (1590).

71 See Morton Klass, Marriage Rules in Bengal, 68 Am. AntHropologist 951, 953-54 (1966). Klass’ observations though dated are still valid. Regional variations do, however, exist particularly between the northern and southern parts of India. In parts of South India, it is common to marry family members.

$$
\begin{aligned}
& 72 \text { See id. } \\
& 73 \text { See id. } \\
& 74 \text { See id. } \\
& 75 \text { See id. at } 960 . \\
& 76 \text { See id. at } 960 .
\end{aligned}
$$




\section{FITTING COLORISM IN A THEORETICAL FRAMEWORK}

The discussion so far has established that colorism exists and is relevant to our present society, though it is as yet unclear whether it exists separately from racism and if so, what distinguishes it from racism. Finding a theoretical explanation for colorism can help clarify these ambiguities, and the logical place to begin this explanation is within the existing sphere of theories.

One may think of the theories of racism discussed below as attempting to provide in rationally explainable terms an answer to the question: what does the discriminator gain, and correspondingly, what do those who are discriminated against lose by engaging in racially discriminatory conduct? Depending on the theory, the discriminator engages in discrimination to satisfy his or her peculiar tastes, statistically determined beliefs or competing social ambitions. Each theory provides a powerful explanation of motives that is useful in understanding such behavior, though each theory also has its own drawbacks. These drawbacks may be a result of the limitations of the tools of applied economics, or they may simply be a result of the theories not taking into account important aspects of discrimination. This Article asks the further question of each theory: do the same explanations of motivations for engaging in racially discriminatory behavior also explain the premium attached to whiteness, which in turn forms the basis for colorism?

In fitting colorism into an existing theoretical framework, this Article tests whether law and economics theories can explain the following phenomena that are relevant to colorism: (1) the existence of colorism in employment markets in the United States, (2) the existence of colorism in the "arranged marriage market" in India, and (3) the near universal desire for whiteness amongst different racial groups. Each of these phenomena is analyzed in three parts. Part A makes a case for Gary Becker's theory of discrimination, referred to as the theory of associational animus; Part B discusses statistical discrimination; and Part $\mathrm{C}$ evaluates the status production theory.

\section{A. Associational Animus}

Gary Becker's theory postulates that discrimination is caused due to individuals' peculiar "tastes for discrimination." 77 That is, because discriminators do not have a taste for associating with certain persons, they wish to avoid contact with them. A taste for discrimination is a "non-pecuniary, psychic cost" that an individual incurs in associating with persons who are the subject of discrimination. ${ }^{78}$ In other words, individuals discriminate when they are willing to pay an amount or forego certain income because of their preference for not associating with certain persons. ${ }^{79}$ For instance, when an employer discriminates against an employee, the employer in effect incurs a non-pecuniary cost in not employing the employee because she may have to pay more to engage another employee (towards whom she has less aversion). Becker suggests that the differential amount paid to employ the preferential employee be used as a measure for discrimination. This is referred to as a "discrimination coefficient" and represents the difference between the monetary price of labor in the market and the true or net wage paid to the non-discriminated against employee. 80 The discrimination coefficient measures the intensity of the employer's taste for discrimination. ${ }^{81}$ According to Gary Becker, in a competitive market, the effect of

\footnotetext{
77 BECKER, supra note 5, at 153.

78 Id.; see generally GARY S. BECKER, THE ECONOMIC APPROACH TO HUMAN BEHAVIOR 7 (1978).

${ }^{79}$ BECKER, supra note 5, at 14.

${ }^{80} \mathrm{Id}$. at 153.

${ }^{81} \mathrm{Id}$. at 39
} 
discrimination is to reduce the demand for those employees who are the subject of discrimination. ${ }^{82}$ However, other scholars argue that employers can have differing tastes for discrimination so that discrimination is more costly for some than others. Employers who do not discriminate and have lower costs of discrimination will then absorb the employees who have been discriminated against. These scholars argue that in a competitive market, market forces will work to absorb the workforce that is discriminated against.

Gary Becker suggests that direct contact between blacks and whites is necessary to develop a desire to discriminate. ${ }^{83}$ Tastes for discrimination can cause either market discrimination, or market segregation, or both. ${ }^{84}$ Becker states that the distinction between market discrimination and market segregation "is essential for a clear understanding of the observable consequences of tastes for discrimination." 85 Segregation occurs when there is less contact between two individuals due to the presence of discrimination. ${ }^{86}$ It occurs because individuals exercise the choice not to associate with members of other groups. ${ }^{87}$ It may be a result of the taste for discrimination, for instance, if intergroup discrimination is greater than intragroup discrimination, individuals may prefer to associate with members of their own group. ${ }^{88}$ Becker states that the taste for discrimination is the most important cause of discrimination but he does not claim that it is the only cause of discrimination. ${ }^{89}$

McAdams has criticized Becker's theory for being both over- and under- inclusive because it does not explain why whites shunned more public associations with blacks such as sitting next to them in buses while engaging in much more intimate associations with blacks such as employing them in household work as well as making black women their mistresses. ${ }^{90}$ McAdams argues that if discrimination was based on tastes for non-association, whites should have more strongly opposed associations with blacks in more private and intimate settings such as that of the home or in sexual relations. In making this argument, however, McAdams may have missed Becker's point that the taste for discrimination may cause market discrimination or market segregation, and that taste is not the only variable in determining actual discrimination. ${ }^{91}$ McAdams's argument relates to segregation rather than discrimination. Separation in buses, restaurants and other public fora are examples of segregation, which may or may not be a result of discrimination. Becker would therefore classify these variations in contact between blacks and whites as segregation caused due to discrimination rather than discrimination per se. Spatial segregation, or the physical separation of individuals in space, is the most common type of

\footnotetext{
$82 \mathrm{Id}$. at 42.

${ }^{83}$ Id. at 154.

84 BECKER, supra note 5, at 157.

${ }^{85}$ Id. .

${ }^{86} I d$.

${ }^{87}$ Id. at $14,157$.

${ }^{88} \mathrm{Id}$. at $159-60$.

${ }^{89}$ Id. at 153.

${ }^{90}$ McAdams, supra note 8, at 1037.

${ }^{91}$ BECKER, supra note 5, at 157.
} 
segregation. ${ }^{22}$ However, segregation may take other forms such as the use of different institutions or the prevalence of hierarchical differences between members of different races in society. ${ }^{93}$ Thus, McAdams's criticism of this aspect of Becker's theory does not affect the strength of Becker's insights on discrimination.

Becker also argues that the nature and type of contact plays an important role in determining discrimination. Therefore, more public associations can produce a greater amount of discrimination. One can argue that in such settings it was more difficult to choose the blacks with whom whites wanted to associate, and even where possible, such choices would be costly to make. Whereas in private settings, whites could easily choose to associate only with the blacks toward whom they did not have a taste for discrimination, such as lighter-complexioned blacks. As such, the obvious disassociation with blacks in public settings may be the most efficient means of reducing contact where it was not otherwise possible to selectively associate.

\section{Does Becker's theory explain colorism?}

Becker intended his theory to apply to all forms of discrimination in the marketplace, including discrimination based on color. ${ }^{94}$ However, in order to be able to explain colorism, one must attempt to logically explain stronger tastes for not associating with darker skin colors. ${ }^{95}$ In other words, are individuals' preferences for not associating with others affected by the lightness or darkness of their skin color? There is some evidence to support such a taste in the data on skin color-based wage differentials. ${ }^{96}$ Becker would claim that this wage differential represents the discrimination coefficient or the cost incurred by the employer in employing a darker- skinned employee.

A taste for associating with persons of lighter skin may have originated from historical explanations of negative images associated with blackness. ${ }^{97}$ This is also supported by studies conducted by Myrdal who contended that lighter-skinned blacks were preferred as slaves by whites because they were more aesthetically appealing to whites ${ }^{98}$ and were thought to be of higher intellect because of their white ancestry. ${ }^{99}$ Historically, lighter-toned slaves were more often assigned to work in situations of

92 See generally Robert R. Weyeneth, The Architecture of Racial Segregation: The Challenges of Preserving the Problematical Past, 27 PUB. HisT. 11 (2005) (discussing the different forms of spatial segregation: partitioning and separation).

93 See, e.g., Mark Schneider et al., Networks to Nowhere: Segregation and Stratification in Networks of Information about Schools, 41 AM. J. POL. SCI. 1201 (1997) (discussing the impact of racial segregation on information sharing networks about educational institutions).

94 BECKER, supra note 5, at 153.

95 One critique of the theory is that, in stating that persons do not desire association with members of a particular race, the theory does not explain the construction of race and how persons are categorized as a race. See McAdams, supra note 8, at 1041-42.

${ }^{96}$ For a study on labor market outcomes of persons with different skin tones, see Arthur H. Goldsmith et al., Shades of Discrimination: Skin Tone and Wages, 96 AM. ECON. REV. 242 (2006) (finding that skin color among African Americans has an important effect on wages).

97 See Baynes, supra note 15, at 137 (citing John M. Kang, Deconstructing the Ideology of White Aesthetics, 2 MiCH. J. RACE \& L. 283, 299-300 (1997)).

98 Thereby depicting the internalization of the norms of the colonizers.

99 See Keith \& Herring, supra note 15, at 762. 
closer proximity to whites and within the sphere of their home whereas darker slaves were generally made to work in the fields and do hard manual labor. 100 The fact that house slaves and slaves assigned to undertake skilled labor were disproportionately found to be lighter-skinned people with mixed racial heritage lends greater credence to the associational animus theory. ${ }^{101}$

In the Indian arranged marriage market, lighter-skinned brides are prioritized and command a premium. ${ }^{102}$ Families of dark-skinned prospective brides have been found to pay large amounts of money in dowry to secure a husband. ${ }^{103}$ Conversely, dark men have been found to marry into poor families so that they can have a lighter-skinned bride. ${ }^{104}$ This dowry or price differential that arises from skin color differences could represent Becker's discrimination coefficient or a non-pecuniary psychic cost that individuals are willing to pay to avoid associating with darker-skinned women.

To extend Becker's theory, assuming that under perfectly competitive conditions, there is perfect substitutability between fair brides and darker brides, some profit-maximizing grooms who do not have such a strong taste for discrimination or place a lower value on fair brides should change their preferences and seek darker brides who may in turn command less accomplished grooms due to their lower value in the marriage market. Similarly, other grooms will also seek out darker brides until equilibrium is reached. Amali Philips finds that arranged marriages are considered to be the means for dark women to find marriage partners for themselves, which otherwise may not be possible. 105 This is consistent with the generally held view among economists that discrimination would be eliminated in a perfectly competitive market. 106

Becker presented the first economic theory of discrimination. This theory finds some support in empirical evidence. Explaining discrimination as a cost to the discriminator may even be a way of reducing discriminatory conduct in the market. However, Becker's theory is simplistic and leaves many questions unanswered, ${ }^{107}$ the primary one being: where does the desire for "whiteness" come from? If one considers the theory that Indian skin color preferences arose from the caste system, it is interesting to note that not in its initial phase but as the caste system evolved social interactions between castes became severely restricted and rigid norms evolved to govern interactions between castes. Segregation

100 See id. This may serve to explain away some part of the criticism of over-inclusiveness of the theory that, if whites did not have a taste for association with blacks, they would not have hired them to work in their homes where association with them at a comparatively intimate level would be unavoidable. See McAdams supra note 8, at 1037.

101 Literature supports the theory that "[w] hen forced to deal with blacks, whites preferred blacks with lighter skin tones." In fact, "[w] hites still seem to prefer and find less threatening persons who look more like themselves." See Jones, supra note 17, at 1513-14. negotiations).

102 See Vaid, supra note 45, at 148 (arguing that complexion has acquired a symbolic capital in arranged marriage

103 See Amali Philips, Gendering Colour: Identity, Femininity and Marriage in Kerala, 46 AnTHropologICA 253, 25354, 266-68 (2004) (describing instances of dowry negotiations in Kerala and the role played by the skin color of the prospective couple in the dynamics of dowry).

${ }^{104}$ Dasgupta, supra note 20, at 22.

105 See Philips, supra note 103, at 269.

106 See Anne C. L. Davies, Perspectives On Labor Law 118 (2004).

107 Another question left unanswered by the theory is why blacks with lighter skin tone would discriminate against blacks with darker skin tone. 
was also practiced by upper caste Hindus. ${ }^{108}$ However, these practices were not a part of early forms of the caste system and it cannot be said that the caste system evolved as a result of tastes for not associating with certain people who may have been of darker skin color. A more commonly accepted explanation is that it was a result of the Aryans' need to maintain status and authority over the indigenous population after their conquest of India. Also, this theory of tastes cannot explain how attitudes towards skin color were perpetuated over time and are prevalent with equal force in the present day. Thus, a theory of tastes for association falls short of explaining why lighter skin color is desired.

\section{B. Statistical Discrimination}

Statistical discrimination provides an account of racism that is based on rationality and shows that it is not necessary for such behavior to be grounded in animus or prejudicial intent. This is different from the status production theory where animus is an important aspect of the theory. However, the idea that statistical discrimination is economically efficient has been criticized as presenting a very narrow and normatively questionable idea of efficiency. ${ }^{109}$ Moreover, since statistical discrimination is not based on actual facts but on discriminatory beliefs, it may be more costly than cost efficient for society.

In his paper introducing the statistical theory of discrimination, Edmund Phelps takes the example of a traveler in a strange town faced with making a choice between eating dinner at his hotel or at another restaurant in town. ${ }^{110}$ Assuming that the costs of acquiring information about restaurants are high and the restaurant at the hotel is believed to be inferior at least half of the time, Phelps argues that it would be rational for the traveler to make a rule that he will eat outside the hotel on every occasion without any prior investigation of restaurant quality. ${ }^{111}$ This remains true even if such a rule can be called discriminatory (against the hotel) and even if, in some cases, the hotel food is better than the food at other restaurants. Similarly, in the context of racial discrimination, a profit-maximizing employer may discriminate against blacks if information costs are high and the employer believes blacks to be less qualified or less reliable. 112 This explains how it is profitable to make discriminatory decisions in certain situations. However, it does not explain why, for instance, in this situation all travelers may choose to eat at the restaurant in town instead of at the hotel. There should logically be an equal proportion of travelers choosing to eat at either the restaurant or at the hotel. In other words, it does not explain how blacks are uniformly disfavored in discriminatory decisions. Moreover, with the passage of time and increased contact, discriminatory decisions may change in that the traveler in Phelps's example may realize that eating outside the hotel is not the better option and may, with time, start eating at the hotel instead. Yet in the context of statistical discrimination, scholars have demonstrated how discrimination

108 At its worst, segregation took the form of terming certain castes to be 'untouchable' and following practices of 'untouchability.' It is tempting to think that untouchability arose from a taste for non-association, in line with Becker's theory, but the history of the caste system shows that untouchability was practiced much after the caste system was established. See Human Rights Watch, Caste Discrimination: A Global Concern, Report to the United Nations World Conference Against Racism, Racial Discrimination, Xenophobia and Related Intolerance, Durban, South Africa, Sept. 2001, available at http:/ /www.ambedkar.org/research/CasteDiscrimination.pdf.

109 McCaffery argues that statistical discrimination may be rational for a firm, but it is not efficient in a public sense. Further, individual firm efficiency has "little normative significance in a world of market failures." Edward J. McCaffery, Slouching Towards Equality: Gender Discrimination, Market Efficiency and Social Change, 103 YALE L.J. 595, 611-12 (1993).

${ }^{110}$ Edmund S. Phelps, The Statistical Theory of Racism and Sexism, 62 Am. ECON. REV. 659 (1972).

${ }^{111} I d$.

${ }^{112} I d$. 
can be self-perpetuating once discriminatory conduct is established over a period of time. ${ }^{113}$ This will be discussed in further detail below.

Individuals can be easily categorized based on race due to the association between race and skin color, and the observability of skin color. If, on average, people of different races differ in productivity due to unobservable causes such as quality of education or cultural differences, the statistical theory of discrimination postulates that employers can profitably use race as a proxy for these unobservable characteristics that come to be associated with race. ${ }^{114}$

Phelps's assumption of high information costs is noteworthy. High information costs may appear to be a restrictive assumption for justifying discriminatory behavior in the present world given that information costs have reduced with improvements in technology. ${ }^{115}$ Kenneth Arrow explains that these information costs do not refer to the easily verifiable or observable qualifications and characteristics of an individual. ${ }^{116}$ Rather, these information costs refer to traits relevant to an individual's employability that are not easily observable such as investments that workers make in themselves in the form of habits of action and thought, steadiness, punctuality, responsiveness and initiative, among others, which all contribute to the qualifications of a worker. ${ }^{117}$ However, these characteristics can be acquired with experience, training and motivation, and therefore, should not in themselves justify hiring decisions.

Strahilevitz, however, shows that an important cause of statistical discrimination is the lack of verifiable information about the subject of discrimination. ${ }^{118}$ One cause for high information costs may be privacy laws that prevent the disclosure of information (for example, criminal history records), thereby encouraging discriminatory decisions that would not be made if employers had more information. ${ }^{119}$ Stravilevitz also shows that government disclosure of previously private information can reduce discrimination if statistical discriminators form a majority of discriminators in the market and the government-disclosed information is relatively accurate. ${ }^{120}$ Thus, information costs are central to statistical discrimination.

113 See Ronald G. Fryer Jr. et al., Experience-based Discrimination: Classroom Games, 36 J. ECON. EDUC. 160 (2005).

114 See Kenneth J. Arrow, What Has Economics to Say About Racial Discrimination, 12 J. ECON. PersPeCTIVES 91, 96 (1998).

115 Professor Richard Epstein makes a similar criticism of statistical discrimination. Parties have enough incentives and opportunities in a free market to overcome high information costs. See McCaffery, supra note 109 , at 612 (citing Richard Epstein, Forbidden Grounds: The Case Against Employment Discrimination Laws 33-41 (1995)).

116 McCaffery makes a similar point by distinguishing between imperfect and incomplete information. Incomplete information is information that is "neither known nor knowable." It is such information which is problematic in the context of gender discrimination. See McCaffery, supra note 109, at 612-13.

117 See Kenneth Arrow, Some Models of Racial Discrimination in the Labor Market 21 (1971).

118 See Lior Jacob Strahilevitz, Surveillance: Privacy v. Antidiscrimination, 75 U. CHI. L. REV. 363, 372 (2008).

${ }^{119}$ Id. at 363-64.

${ }^{120} I d$. at 373 . 
In his paper discussing racial discrimination in labor markets, Kenneth Arrow argues that statistical discrimination will occur only when employers incur "personnel investments." 121 Personnel investments are costs incurred by employers every time a worker is hired and includes the cost of training. ${ }^{122}$ According to Arrow, if there were no personnel investments, an employer would hire everyone who applied and simply fire those unqualified after evaluating their performance. ${ }^{123}$ However, personnel investments make changing the labor force from black to white or vice versa a costly proposition. ${ }^{124}$ Given the costs associated with personnel investments, employers should be wary of making any mistakes in their hiring decisions. Arrow thus explains that statistical discrimination occurs in order to reduce the possibility of costly mistakes arising as a result of an employer's inability to completely evaluate the qualifications of prospective employees. In a costless world, of course, an employer would have all the information required to arrive at a correct hiring decision and then would hire an employee who would be least likely to sink the personnel investments made in her.

This explanation presumes that either it is impossible to obtain accurate information about certain personal attributes or characteristics of people, or information costs are higher than the costs associated with mistaken decisions such as the cost of hiring an unsuitable person who may need to be dismissed from service after personnel investments have been incurred. Otherwise, employers would invest in acquiring the correct information about prospective employees (given that mistakes can be costly in the form of sunken personnel investment costs) rather than use proxies to predict the potential characteristics of potential employees. This assumption of high information costs, while central to the statistical theory of discrimination, limits the scope and applicability of this theory.

Discriminatory conduct arising as a result of statistical discrimination can be perpetuated over a period of time. One of the reasons for this may be a rational worker's unwillingness to invest in human capital in light of discrimination. ${ }^{125}$ When prospective employers make judgments based on race rather than the ability and qualifications of individuals, those individuals who are hired are not rewarded for the investments they make in acquiring these qualifications, which will in turn reduce the individual's motivation to invest in acquiring these qualifications, leading to a cycle of self-perpetuating statistical discrimination. ${ }^{126}$ In other words, if individual A loses a job at an interview to competing individual B due to discriminatory beliefs about A's abilities (even though both A and B are equally qualified), other members of A's community will be unwilling to invest in the skills that A acquired since they will not consider it a worthy investment to make in light of A's failure to obtain the job despite making the investment in acquiring the skills. This will in turn make those members less qualified and less able to obtain employment. In the context of gender-based discrimination, McCaffery makes a similar point that women are less inclined to pursue an education than men because of the lower salaries they are likely to

121 ARROW, supra note 117, at 21.

${ }^{122} I d$.

${ }^{123} I d$.

${ }^{124}$ Id. at $19-20$.

125 Daria Roithmayr, Barriers to Entry: A Market Lock-in Model of Discrimination, 86 VA. L. REV. 727, 731 (2000) (citing Cass R. Sunstein, Why Markets Don't Stop Discrimination, in FrEE MARKETS AND SocIAL JusTICE 151, 153-54, 157-58 (1997)).

126 See ARROw, supra note 117, at 96-97. 
earn as a consequence of statistical discrimination. ${ }^{127}$ This lack of education further reduces their salaries. ${ }^{128}$

Roithmayr uses principles of antitrust to argue that market discrimination is "locked-in" because of historical monopolistic conduct by whites, which created barriers to entry for blacks so that standards of competition that favored whites were locked in by the market over a period of time. ${ }^{129}$ Due to market mechanisms, an initial advantage can feed back on itself to create an even larger advantage until that advantage becomes so large that it becomes "locked-in."130 Thus, racism persists because blacks do not enjoy the same opportunities to compete. The culturally specific standards of competition that have been institutionally locked in by white monopolistic conduct favor whites and create barriers to entry for blacks in a self-perpetuating cycle of discrimination. ${ }^{131}$ Statistical discrimination can therefore explain the persistence and prevalence of racism in society.

\section{Can statistical discrimination explain colorism?}

Does the statistical discrimination theory help explain why whiteness is valued? The foundation for this theory lies in the ability and ease with which it is possible to characterize people into different groups, and then make generalized assumptions about their characteristics based on their membership in a group. Does the presence of a variety of shades of skin color make this characterization more costly? Can skin color (unconnected with race) be used profitably as a proxy for making employment decisions?

For statistical discrimination to be profitable, the following conditions should be met: (a) high information costs, (b) the ability to clearly classify people into groups and (c) the ability to make correlations between the group's attributes and its productivity. The assumption of high information costs and the restrictiveness of that assumption is the same for colorism and racism.

It is possible to make correlations between skin color and productivity as suggested in (c) above. Not only have such correlations been made, but they also have a basis in history. For example, in America, people with lighter skin tone, who were also persons of mixed racial heritage, were generally found to be better educated and wealthier, as they had the opportunity to capitalize on their white ancestry. This indicates that people associated lighter skin color with white heritage and that association consequently led to better education and more opportunities.

Empirical evidence suggests that employment decisions in the present day are also affected by skin color. ${ }^{132}$ In fact, a variety of studies conducted recently in the American labor market have found a

127 See McCaffery, supra note 109, at 623 (citing Ian Ayres, Price and Prejudice, New RePubliC, July 6, at 32 n.101). Recent research suggests that this may no longer be a concern as women constitute a significant share of college students in the United States.

128 Id. at 623 .

${ }^{129}$ Roithmayr, supra note 125 , at 731-32.

${ }^{130}$ Id. at 732 .

131 Id. at $734-35$.

132 See, e.g., William A. Darity Jr. \& Patrick L. Mason, Evidence on Discrimination in Employment: Codes of Color, Codes of Gender, 12 J. ECON. Perspectives 63 (1998) 
gradient of better opportunities for persons with lighter skin color. ${ }^{133}$ Therefore, a positive correlation can be drawn between skin color and the presence of unobservable attributes. These distinctions are not made purely based on skin color; rather, they are made because people of lighter skin color are assumed to be of white ancestry and consequently have the benefits that are associated with being white. Such correlations are thus, racist rather than colorist because they are related to the employer's belief in the historical link between the color and race of a prospective employee. This reasoning does not satisfactorily explain how employers and other decision makers draw fine distinctions between people of different skin color, and needs more in-depth study, which is beyond the scope of this Article.

Finally, with respect to (b) above, given the different shades of skin color (as compared to the specificity of racial groupings), colorism belies the ease of classification into groups that racism promotes. It does not seem efficient to identify different skin tones and categorize individuals into a multiplicity of hues just to avoid high information costs. Moreover, groups based on color will not be well defined so there are likely to be ambiguities about the classification of individuals into such groups. If it is difficult to classify individuals into groups based on skin color, then it will be correspondingly difficult to make assumptions about group attributes. There is a greater chance of decisions being made wrongly because of ambiguities in color-based classifications. While classifications based on race are clear and therefore easy to make, classifications based on skin color have an element of ambiguity that makes them complex. Hence, it is less profitable for employers to make such decisions. It is doubtful that statistical discrimination will be efficient in the absence of clearly defined groups.

In the Indian arranged marriage market, prospective brides and grooms seek mates with certain characteristics. Some of these characteristics are easily observable while others are not. A few examples of observable characteristics are beauty, family background and education. Examples of unobservable characteristics are health, cultural and social values, and behavioral qualities-characteristics that can only be known with time and familiarity. Because marriages are typically fixed soon after the time that the alliance is brought to the attention of the families and interaction between the prospective partners is strongly discouraged, unobservable characteristics are difficult to determine. Skin color serves as an identifiable proxy for some of these traits; light skin color is associated with better breeding and higher social status. ${ }^{134}$

From the discussion above, it is clear that information costs are high in the Indian arranged marriage market. It is also clear that Indian arranged marriage market participants attribute positive traits to prospective partners of lighter skin color. Thus, in making a choice between darker-complexioned girl $\mathrm{A}$ and lighter-complexioned girl B, the male will choose girl B if he knows equally little about both girls and her observable characteristics are equivalent to girl A. Because marital decisions have been made on this basis for a long period of time, it is possible to argue that light skin has become so firmly established as a proxy for positive attributes that it is now a necessity for a prospective bride. ${ }^{135}$ Even if there is

133 For a study on labor market outcomes of persons with difference skin tones, see Arthur H. Goldsmith, Darrick Hamilton \& William Darity Jr., Shades of Discrimination: Skin Tone and Wages, 96 AM. ECON. REV. 242 (2006) (finding that skin shade among African Americans has an important effect on wages).

134 See Philips, supra note 103, at 253 (discussing the conceptions of skin color in Kerala, a state of India, and the social judgments that color brings with it, as well as describing existing literature in social science about the importance of skin color in South Asian arranged marriages).

135 See Vaid, supra note 45, at 149 (noting that the association between light skin and marriage prospects starts at the birth of a female child with relatives commenting upon the gender and next the skin color of a new born baby); see also Serena Nanda, Arranging a Marriage in India, in Stumbling TOwArd TruTH: ANTHropologisTS AT WORK 196, 196-204 (Philip R. Devita ed., 2000) (stating that skin color is an important consideration in Indian arranged marriages). 
more information about girl A than girl B, the complexion of girl B is likely to make her a more successful candidate for marriage. Only if sufficient negative characteristics can be imputed to the lightskinned girl, will she be disqualified as a marriage candidate. In fact, because fair complexion has come to be associated with beauty in general, 136 even individuals choosing partners outside the arranged marriage market, where information costs are relatively low, prefer partners of a lighter skin color. Moreover, the fact that discriminatory beliefs are uniformly held across racial and national divides fits well within the theory of statistical discrimination. In sum, statistical discrimination can explain why decisions about prospective marriage partners are based on skin color.

One shortcoming of statistical discrimination is that it cannot explain the complexities and intricacies of interactions in society that are affected by skin tone. It does not explain how skin color rather than some other equally visible attribute such as hair color is used as a proxy for making statistically based decisions. The associations between the race of a person and certain characteristic attributes, which, prima facie, have no actual relation with race, are created by society. There seems to be no basis for the creation of statistical beliefs about skin color in Indian history. The discussion on the origin of the caste system in India (in Section III of this Article) suggests that initial caste divisions may have been based on skin color. However, skin color is no longer relevant in determining the caste of a person. Skin color is not even a proxy for caste in an arranged marriage as skin color and caste are distinct requirements that need to be met. Statistical discrimination cannot explain how such deep-rooted beliefs regarding the positive attributes of being white have come about, even amongst darker-skinned individuals. ${ }^{137}$ It cannot explain the desire for whiteness.

\section{Status Production}

The status production theory postulates that racial discrimination arises from a desire for status. The theory finds support in the fact that the effect of racially discriminatory behavior has historically been the appropriation of status by whites. ${ }^{138}$ The theory is based on the desire to be socially esteemed and in particular, to seek status in small, close-knit communities that McAdams calls "socially connected groups." 139 McAdams argues that the desire for status is so great amongst members of socially connected groups that it motivates individuals to make material sacrifices for the sake of gaining status within a group. ${ }^{140} \mathrm{He}$ then applies this argument to society as a whole. Members of a socially connected group materially contribute to improving their inter-group status, so creating status for their group vis-à-vis

136 See, e.g., Vaid, supra note 45, at 149 (describing Indian dietary practices to ensure that pregnant women give birth to a light-complexioned child because of the association Indians make between light skin color and beauty).

137 There is a rich supply of literature on what whiteness brings with it and the social construction of these benefits. For a comprehensive account bringing together different theoretical traditions, see DAVID R. ROEDIGER, THE WAGES OF WhitenESS: RACE AND THE MAKING OF THE AMERICAN WORKING Class (1991).

138 McAdams, supra note 8, at 1044 (citing RoEDIGER, supra note 137 at 13, and Derrick Bell, White Superiority in America: Its Legacy, Its Economic Costs, 33 VILL. L. REV. 767, 774 (1988)). See also Harris, supra note 10, at 1745-46 (describing how the acceptance of white privilege in law in the period after the abolition of slavery contributed to the creation of whiteness as status); see also Dasgupta, supra note 20, at 23 (presenting a view based on Indian colonial history that fair skin represents social superiority in India).

139 McAdams, supra note 8, at 1023-24.

${ }^{140} I d$. at 1031. 
other groups means that they will be esteemed by other groups because of their membership in the esteem producing group. ${ }^{141}$

According to McAdams, status is not only a means of bringing about, but also an end of intragroup cooperation. ${ }^{142}$ Individuals cooperate with each other because they want to be esteemed by others and such cooperation results in esteem for the group as a whole. Status is the reason for cooperation among individuals as well as a result of the cooperative endeavor. Intra-group cooperation, on the other hand, brings about inter-group conflict in the form of competition for inter-group status. ${ }^{143}$ Since social status is relative in that it is acquired in relation to others, investing in increasing the status of one's group means subordinating the status of other groups. ${ }^{144}$ McAdams adds that the desire for status increases cooperation among members of a group. ${ }^{145}$ Racism is a product of this desire for status.

\section{E. How does status production explain free riding?}

Any theory of group behavior is faced with the challenge of being able to rationally explain how the tendency of members to free ride is overcome. ${ }^{146}$ McAdams's status production theory argues that racial status production will occur even in the absence of any external coercion ${ }^{147}$ as long as socially

$$
\begin{aligned}
& { }^{141} \mathrm{Id} \text {. at } 1045 . \\
& { }^{142} \mathrm{Id} \text {. at } 1029 . \\
& { }^{143} \mathrm{Id} . \\
& { }^{144} \mathrm{Mc} \text { Adams, supra note 8, at } 1031 . \\
& { }^{145} \mathrm{Id} \text {. }
\end{aligned}
$$

146 The tendency to free ride arises when a good is non-excludable, and an actor internalizes all of the immediate costs of contributing to it, but only receives a part of the diffuse future benefits from the provisioning of the good. These goods are available for the enjoyment of all, regardless of who has contributed to producing them. Thus, a rational individual will not contribute to the production of such goods because it is possible for the good to be produced and for the individual to enjoy its benefits without contributing to its costs. This behavior of benefiting from the efforts of others is known as free riding. As a result, there is little incentive to produce either a suboptimal amount of the good, or no amount of the good is produced. This is known as the "free rider problem." Studies have shown that factors such as group size, the noticeability and perceptibility of the contribution, and an individual's share in the benefits can affect the motivation to free ride. Free riding occurs when goods are collectively owned. See Lee A. Fennel, Common Interest Tragedies, 98 Nw. U. L. REV. 907, 919 (2004); Robert Albanese \& David D. Van Fleet, Rational Behavior in Groups: The Free Riding Tendency, 10 ACAD. MgMT. REV. 244, 244 (1985). The classic example given of the free riding problem is voting in a democracy. It is possible to benefit from a change of government in a democracy without physically participating in the process of voting. However, a new government cannot be formed if no one votes. See also RICHARD TUCK, FREE RIDING 30 (2008).

${ }^{147}$ In his book on the theory of collective action, Mancur Olson showed that large groups will not be able to produce public goods in the absence of external coercion. See MANCUR Olson, The LOGIC OF COLLECTIVE ACTION: Public GOODS AND THE THEORY OF GROUPS (1971). Richard Tuck has succinctly described Olson's idea, “Coercion, on his [Olson's] account, was justified only in these cases, where the fact that any one person's contribution was negligible [in comparison to the whole] rendered the whole enterprise impossible without an external apparatus of compulsion. People in these instances have to be forced to do what is undeniably in their own interests." TUCK, supra note 146, at 5. Olson took the example of the union closed shop to explain coercive mechanisms designed to prevent freeriding. $I d$. at 8 . The closed shop was an agreement between labor unions and employers where the employer agreed to employ only members of a particular labor union and accordingly employees were forced to agree to be members of that labor union for the duration of their employment. Elinor Ostrom has argued that collective action will be possible even without coercion where groups develop social norms. See ElinOr Ostrom, Governing THE COMmONs: THE EVOLUTION OF INSTITUTIONS FOR COLLECTIVE ACTION (1990). 
connected groups overlap substantially with intra-racial or shared trait groups. ${ }^{148}$ Socially connected and shared trait groups naturally overlap, according to McAdams, because the very visibility of skin color as a shared trait makes it advantageous for whites to come together as socially connected groups to create status. ${ }^{149}$ The status production theory thus presumes that individuals have a tendency to group together based on race and will overcome the urge to free ride because (a) they strongly desire to be esteemed by others, and (b) skin color is the ideal criterion for social grouping for the purpose of status creation. ${ }^{150}$

Considering presumption (a) above first, McAdams's devotion to the concept of esteem and the willingness of individuals to cooperate for the sake of esteem may be restrictive. When an individual's desire for status is so strong, McAdams does not explain how individuals overcome the desire to create esteem for themselves by subordinating, rather than cooperating with others. In other words, he does not adequately explain why individuals invest in allocating esteem to others rather than invest in creating status for themselves. Individuals will value esteem differently and all members of a socially connected, shared trait group may not be willing to incur the same costs to generate esteem; the latter costs borne for status creation.

Now considering presumption (b), can the mere visibility of skin color be responsible for overcoming free riding? The visibility of skin color is an important aspect of McAdams's theory because it makes it easy to monitor defections or free riding by group members. ${ }^{151}$ The easier it is to identify noncontributing group members due to their physical characteristics or other factors, the easier it is to punish them for not contributing. Punishments can take the form of social ostracism and stigmatization, or something more coercive.

Epstein opines that the argument against free riding does not take into account the ease of mobility as evinced by the new entry of and defection by certain subgroups. McAdams acknowledges that each socially connected subgroup will have a tendency to free ride when many socially connected groups comprise one shared trait group. ${ }^{152}$ Given that all whites are not socially connected, some socially connected white subgroups will likely free ride on the investments of other whites. McAdams argues that status production will still occur because those socially connected white subgroups with lower status and few other options for status production will benefit from racial subordination. ${ }^{153}$ This is in line with Olson's idea of voluntary collective action in small group sizes. ${ }^{154}$ However, it is difficult to see how status can be produced if free riding is extensive. If some whites do not indulge in discrimination and do

148 See McAdams, supra note 8, at 1047.

${ }^{149} I d$. at $1047-48$.

150 The more observable the trait, the more status members have to gain by joining the group. Id. at 1045-47

151 According to McAdams, the use of observable traits as proxies for granting esteem gives people a reason to care about the esteem generating behavior of others with whom they share the observable trait. Esteem makes cooperation rational. $I d$. at 1022 .

${ }^{152} I d$. at 1046.

${ }^{153} I d$. at 1047.

154 See generally OLSON, supra note 147 (arguing that small groups are qualitatively different from large ones and the structure of small groups creates economic and social incentives that helps to induce voluntary collective action in them. Thus, small groups produce public goods more effectively than larger groups. When applied to the status production theory, this means that members can more effectively produce status in socially connected groups through esteem allocation due to the smaller size of these groups.). 
not distinguish blacks in any way from themselves, the effect of the investments of other white subgroups will be diluted and may even be nullified. This occurs particularly when white subgroups who are not indulging in discrimination are likely to be the ones with higher social status. A majority of white subgroups must at least be ready to allocate esteem to other whites who are creating status in order for the status production theory to work. But McAdams does not explain why elite white subgroups will allocate esteem to whites with lower social status.

Another argument that McAdams puts forth is that free riding will be overcome by the presence of discriminatory social norms that transcend individual subgroups. ${ }^{155}$ Epstein argues that the theory is wrong in concluding that status production (or only social and cultural norms) is powerful enough to motivate group solidarity in the absence of force or coercion. ${ }^{156} \mathrm{He}$ also argues that the techniques of status production are not exclusively available to whites. Blacks can also create status for themselves and the theory does not sufficiently take this into account. ${ }^{157}$ The following discussion provides a possible explanation for why blacks may not attempt to create status for themselves.

\section{F. Applying the theory of status production}

The status production theory is able to explain the desire for whiteness. As with statistical discrimination, the status production theory is also premised upon the visibility of skin color. This makes race an easily identifiable marker for defining and creating shared-trait groups. The visibility of skin color plays an important role in status creation. ${ }^{158}$ McAdams argues that whiteness is a visible trait that is associated with higher status because of the investments that whites have made in status production. ${ }^{159}$ These investments then explain the desire for whiteness, which is the desire for the privileges and status that are associated with possessing white skin color. ${ }^{160}$ Skin color has served as more than an indicator of class. It was the determinant of status regardless of a person's actual socio-economic class. ${ }^{161}$ This is because whites have used skin color to create status for themselves. The status production theory can explain the desire for whiteness by relying on the association between color and status. This association explains the value society places on whiteness.

The status production theory can also partially ${ }^{162}$ explain why blacks and other people of color value whiteness even though it is a characteristic that they do not themselves possess. For example, members of a dark-skinned Indian family will nevertheless reject a prospective bride who is dark-skinned in favor of a light-skinned bride even though the family may share the same skin shade as the dark-

${ }^{155}$ Id.; McAdams, supra note 8, at 1047.

156 Richard A. Epstein, The Status Production Sideshow: Why the Antidiscrimination Laws Are Still A Mistake, 108 HARV. L. REV. 1085, 1091-92 (1995).

${ }^{157} I d$. at 1106.

158 McAdams, supra note 8, at 1045.

${ }^{159} \mathrm{Id}$.

${ }^{160}$ Jones, supra note 17 , at 1528.

${ }^{161} I d$.

162 The status production theory can only partially explain this because its explanation for why groups create status for themselves is based on the assumption that people tend to esteem characteristics in others which they also possess themselves, an assumption that is proved untrue in this case. 
skinned bride. This is because the characteristic of whiteness is associated with a group that has created status for itself. In this way, investing heavily in status accorded to whiteness, ${ }^{163}$ whites have been able to ensure that their beliefs associated with whiteness acquired the form of a social norm that was internalized by all of society. ${ }^{164}$ Through their discriminatory interactions with whites, blacks are reminded of the benefits of being white and of the inferiority of being black. The desire for whiteness, then, is a desire to seek membership of the group believed to have a higher status.

Further, while people generally care about what others think, it is possible to use the status production theory to make a claim that, in particular, people care more for obtaining the esteem of persons who are highly placed in society than the esteem of group members who are no better off than themselves. ${ }^{165}$ This is not to say that the esteem of other blacks does not matter to blacks, but the desire for membership in the group with superior status may be stronger than the need for esteem from the fellow members of a socially subordinated group. According to the status production theory, members of a socially connected group give esteem to those members of their group, who participate in the creation of group status. In a situation where members of a group concede their inferior position, ${ }^{166}$ the group may invest in acquiring visible traits that others consider valuable, rather than trying to generate esteem for their own shared trait group. ${ }^{167}$ Thus, internalizing the views of the more powerful and dominating members of society, like whites, is one possible reason for intra-racial colorism. ${ }^{168}$

In this situation, there is no motivation to invest in creating status for one's own group, as no payoffs are being achieved from group membership. Members may no longer feel it profitable for them to remain in that group but instead may strive to attain membership in another group. ${ }^{69}$ As acquiring the traits of other groups does not require the cooperation of group members, it may result in a loss of value in membership of the subjugated group. This may explain the feeling of low self-esteem among darkerskinned people, as well as their desire for whiteness. ${ }^{170}$ Since negative feelings regarding dark skin color are common to members of a group, these attitudes do not fracture the existence of the group itself.

163 See McAdams, supra note 8, at 1046.

164 Social norms can arise amongst a collection of socially connected groups. $I d$. at 1047.

165 We tend to value most the opinion of those we esteem highly. Id. at 1024. In a situation where internalization of norms has resulted in greater esteem for persons who are believed to represent an ideal which a person is striving to reach, this could be a person of another group. Thus, all persons of a group may esteem an ideal which they do not possess.

${ }^{166}$ Frequent exposure to negative evaluations can undermine the sense of self-worth. Self evaluations have an effect on a person's moral worth as well as her competency or efficacy. Interestingly, the effect of colorism is different for women and men. Skin tone has a significant effect on self-efficacy of black men and on the self esteem of black women, though the findings in the study are moderated for socio-economic status in the case of women. Maxine S. Thompson \& Verna M. Keith, The Blacker the Berry: Gender, Skin Tone, Self Esteem and Self Efficacy, 15 GENDER \& SOC'Y 336, 339 (2001).

167 McAdams, supra note 8, at 1045.

168 Nance, supra note 30 , at 443.

169 This explains the attempts by blacks with lighter skin tones to pass as white.

170 Studies show that skin color and not achievement determines identity and values about the self. Skin color is positively related to feelings of self-worth and attractiveness. The study also points out how the effect of darker skin color is much more on women than men. However, a deeper examination of this interesting interplay of race and sex discrimination is beyond the scope of this paper. See Thompson \& Keith, supra note 166, at 337. 
Moreover, given that such attitudes are shared and are generally accepted, group members are not punished by other members for behavior that reduces the group's esteem.

The behavior of blacks and people with mixed racial heritage during the Jim Crow South suggests that it was too costly for those groups to invest in the subordination of whites. Instead, it was more profitable to accept white superiority and align oneself with whites. ${ }^{171}$ For instance, some people with mixed racial heritage believed that their white blood made them superior to other black slaves. ${ }^{172}$ People with mixed racial heritage were thus using the value-ridden property of "whiteness" to create status for themselves. ${ }^{173}$ Rather than group together to subordinate whites, people with mixed racial heritage and blacks competed to subordinate each other, and they accepted white superiority. Furthermore, studies have shown that lighter-skinned blacks, or people with mixed racial heritage, took pains to maintain their distinctive status by engaging in conscious acts with the objective of furthering group interests. An example is their insistence on endogamy. ${ }^{174}$ These historical studies strengthen the explanatory power of the status production theory.

\section{G. Can the status production theory also explain colorism?}

At first glance, the theory of status production explains some of the history of American colorism. For example, the systematic exclusion and disparagement of blacks by the formation of social networks such as the brown paper bag ${ }^{175}$ and blue-vein ${ }^{176}$ societies may be seen as the status production theory at work. These societies present a micro-picture of how skin color was used to create social hierarchies.

Firstly, these societies attempted to create and define an identifiable group on the basis of skin color where the inherent foundation for a group, or some other unambiguous boundary, did not exist naturally. ${ }^{177}$ The very essence of the distinction on which whites built their status_-skin color-is eroded when the distinction between black and white is blurred by the creation of an intermediate category of

171 An important part of the game of status production is to gain the approval of third party observers. A strategy would be to eliminate the existence of the third party group by including them in either one's own group or the disparaged group and since it is better to be a part of the majority, all else equal, this strategy would involve defining one's self as a part of the majority. McAdams, supra note 8, at 1049. 15 , at 762 .

172 Skin tone was an important criterion for attaining prestige in the community. See Keith \& Herring, supra note

${ }^{173}$ It is no surprise that people with mixed racial heritage patterned their behavior on whites. Id. at 763.

174 The disproportionate intermarriage amongst people with mixed racial heritage is contended to be the effect of a strong social norm enforced by their elite in order to preserve distributional rents associated with being such a person. See Howard Bodenhorn, Colorism, Complexion Homogamy and Household Wealth: Some Historical Evidence, 96 Am. ECON. REV. 256, 256, 259-60 (2006). See also Keith \& Herring, supra note 15, at 760-61.

175 The "brown paper bag" societies excluded membership of those blacks whose skin was darker than the color of a brown paper bag. See Keith B. Maddox, Brown Paper Bag Syndrome: Darker Skinned Blacks are Subject to Greater Discrimination, 37 J. BLACKS Higher EduC. 46 (2002) [hereinafter Brown Paper Bag Syndrome].

176 The "blue-vein" societies' membership was restricted to those persons whose skin color was light enough for their veins to be visible. See Baynes, supra note 15, at 141.

177 In some of these societies, people were admitted solely on the basis of their skin color regardless of their socioeconomic status. This was probably an extreme attempt at drawing a group boundary. 
people with skin color that falls within a diverse range between black and white. ${ }^{178}$ Diversity of skin tones makes it difficult to create distinct groups based on skin color. However, these societies used innovative methods of achieving group exclusivity by objectively determining the precise skin tone required for membership in the group. Group members could then make investments in status production with less fear of free riding. Secondly, these color-discriminating societies show that skin color could be used as a means for status creation.

The theory of the origins of the Indian caste system based on a color hierarchy created by the Aryans also points towards a link between skin color and status that supports the status production theory. If the theory is correct, then it is possible to say that the behavior of the Aryans in creating social (or occupational) hierarchies based on skin color or varna was their attempt at creating a system of clearly defined groups that preserved their status by making the group to which they belonged the socially superior one. This fits neatly into the explanation provided by the status production theory.

The status production theory can also be used to explain colorism in present-day society. Societies make strong correlations between light skin color and higher social status. American employers may want to hire people with lighter skin color and Indian men may seek brides with light skin color because they feel that such people come from a higher stratum of society and are consequently better situated to be employees or marriage partners, respectively. Therefore, associating with such people will increase their own status. If one considers marriage to be a strategic decision of improving or establishing one's social status, ${ }^{179}$ then the premium associated with a fair-skinned bride, in the form of a demand for a higher dowry for darker brides, is explained perfectly.

Setting aside historical and present-day examples, can the theoretical precepts of status production be used to explain colorism? The interconnectedness of socially connected and shared trait groups is an important part of McAdams's theory as it explains why individual members of a group will allocate esteem to other group members. However, it is difficult to extrapolate the connection between shared trait and socially connected groups in the case of colorism because people who share the same skin tone may not always be a part of the same socially connected groups, and vice versa. Given the diversity of skin colors, sometimes even among members of the same family, 180 natural social connections are drawn between people of different skin color. In fact, very often, close family members can exhibit widely variant skin tones. ${ }^{181}$ As a result, the advantages that overlapping socially connected and shared trait groups provide to status creation in the case of racism is difficult to replicate with colorism. Colorism blurs the color line, it shifts the paradigm of discussion from a simple black and white one to a more ambiguous one of whiteness and darkness.

178 McAdams acknowledges that, as cross-membership between groups increases, people will invest less in subordinating other groups to which they may also belong. McAdams, supra note 8, at 1080. Yet this category of mixed race people is not a product of the new age. They always existed. Their existence has, however, not undermined the ability of whites to create status for themselves. Examining the reasons for this is beyond the scope of this study.

179 Indian and European history is replete with examples of rulers and kings marrying strategically to further their interest or status. When families look for prospective spouses for their children in an arranged marriage, the primary concern of the parents is that the child should marry into a family with status.

180 For example, the protagonist in Eliot's MiLl ON THE Floss, Maggie Sullivan was dark complexioned whereas her brother was fair complexioned. See generally ELIOT, supra note 1.

181 See Adewunmi, supra note 28 (describing the different skin shades of members of the author's family from "white in certain lights" to "deep brown" to "dark as night"). 
Taking this argument one step further, introducing colorism into the status production theory means acknowledging that there are a variety of skin colors within a race and that shared trait groups and intra-racial groups are not superimposable. Members of the same race do not necessarily share the same skin color and therefore cannot form a part of a shared trait group. The basis of McAdams's argument that the trait common to members of a race is skin color, and thus, shared trait groups are actually intraracial groups cannot stand unless members of a race can be said to group together based on their specific skin tone. Since we do not generally observe such groupings in society, McAdams's argument of intragroup cooperation by reason of esteem allocations to other group members, as well as his arguments for why free riding will not occur, cannot explain colorism.

It is possible to take a different view of this by considering how whites have responded to groups who have tried to free ride on whites' investments in status production. On the one hand, history shows that whites' response was to preserve the distinctiveness of group boundaries by resorting to mechanisms such as the "one drop rule." 182,183 This is consistent with the status production theory because preserving group boundaries is necessary to avoid free riding on whites' investments in status production. On the other hand, whites created a divide based on skin color by actively favoring lighterskinned blacks over darker-skinned blacks. ${ }^{184}$ One way to explain why whites created this distinction is that by distinguishing persons on the basis of skin tone, whites re-emphasized their own superiority in the so-called racial hierarchy. Giving preference to people who were more akin to whites in terms of their most visible characteristic, skin color, and the benefits attendant to such preference like higher status, was a way to strongly reinforce the benefits associated with "whiteness" and thereby create a social hierarchy or normative structure in which the characteristic of whiteness was an ideal desired by all non-whites. This explanation is also consistent with the general idea of status production.

To conclude, the idea that colorism can be a result of the desire to create status is compelling, and both historical and present-day examples exist to support such a thesis. However, the theory's explanation of how status is created falls short of explicating colorism.

The discussion that follows attempts to apply the understanding of colorism derived from the above to developing a legal framework for colorism in India.

182 Any person with even a drop of black blood was considered to be black and thus not white. See Jones, supra note 17 , at 1505 .

183 The status production theory explains why rigorously enforcing boundaries between races pays off. McAdams, supra note 8, at 1049 n.182.

184 Blacks with lighter skin tone report dramatically better treatment from whites and partially better treatment from blacks than those with darker skin tone. See Hersch, supra note 17, at 251. In the majority of the cases, people with mixed racial heritage with their lighter skin tones were admired by blacks. See Jones, supra note 17, at 1517 . Whites and lighter skinned blacks have been found to have deep-seated beliefs that dark-skinned blacks are more prone to violence, criminal activity, drug use, and laziness. See Brown Paper Bag Syndrome, supra note 175, at 46. According to McAdams, under the status production theory, people of a particular racial group invest in group boundaries to maintain their position in high status groups. McAdams, supra note 8 , at 1045 . However, since the goal of status production is to subordinate by gaining the approval of third party observers, McAdams suggests that an obvious strategy would be to eliminate third party observers by including them in one's own group thereby defining ones group as the majority. See McAdams, supra note 8, at 1049. Therefore, status production can explain the need to define oneself as belonging to the majority group. Id. 


\section{COLORISM AND THE LAW IN INDIA}

The discussion on racial discrimination and the law in India is superimposed with the dialogue on caste-based discrimination. While the media ${ }^{185}$ and academics ${ }^{186}$ discuss racism and colorism in India, there is little by way of law to support this discussion. Human rights advocates and other legal activists have also not considered racism as a prominent form of discrimination in India. The only legal provision that could be used to redress racism in India is Article 15 of the Constitution of India, which prohibits all forms of discrimination, including discrimination based on race. ${ }^{187}$ In addition, section 153, clauses (a) and (b), and section 505 of the Indian Penal Code of $1860^{188}$ prohibit actions that promote disharmony, hatred, and feelings of enmity and ill will on grounds of race. These provisions also distinguish between race and caste. However, no case primarily alleging racism has been brought before Indian courts. ${ }^{189}$ This has led the United Nations Committee on Elimination of Racial Discrimination ("CERD") to question whether individuals are sufficiently informed about their rights against discrimination. The CERD has also expressed concern that there is no "specific statute providing for the right of individuals to seek from the courts just and adequate reparation or satisfaction for any damage suffered as a result of acts of racial discrimination." 190

Furthermore, while the law addressing racism in India is limited and may not be adequate, there is absolutely no law that addresses colorism in India. Article 15 of the Constitution of India is titled "Prohibition of discrimination on grounds of religion, race, caste, sex or place of birth."191 Discrimination based on color is not recognized as a ground of discrimination in the Indian constitution. Therefore, under the present legal framework in India, people facing discrimination based on color have to bring claims of racism.

Discrimination based on color is not legally recognized in India. However, racism is prohibited under the Constitution of India. This Article demonstrates that even though colorism may have historically originated from racism, in its present form, it is distinct from and unrelated to racism. This difference does not take away from the need to eradicate colorism. ${ }^{192}$ It is also important for the law to distinguish colorism from racism, as racism is much easier to monitor and regulate. This is because racism operates in the public sphere, where colorism manifests more in the sphere of private relations such as marriage.

\footnotetext{
185 See Dasgupta, supra note 20, at 16.

186 See, e.g., Mara Adelman \& Sonora Jha, Looking for Love in All the White Places: A Study of Skin Color Preferences on Indian Matrimonial and Mate-Seeking Websites, 1 STUD. IN S. ASIAN FILM AND MEDIA 65 (2009).

187 INDIA CONST. art. 15.

188 The Indian Penal Code, No. 45 of 1860, PEN. CODE, available at http://indiacode.nic.in.

189 See U.N. Comm. on the Elimination of Racial Discrimination, Consideration of Rep. Submitted by States Parties Under Art. 9 of the Convention: Concluding Observations of the Comm. on the Elimination of Racial Discrimination: India, 9 18, U.N. Doc. CERD/C/304/Add.14 (Sept. 17, 1996).

${ }^{190} I d$. at 25.

191 INDIA CONST. art. 15.

192 See contra Hersch, supra note 17, at 251 (showing that the perceptions of the impact of colorism in society may be greater than the actual differential treatment given to people of different skin shades).
} 
The legal framework in India should be sensitive to this difference, and "color" should feature as a separate ground of discrimination. A question for future research is whether, even if color is included as a ground of discrimination, it will be able to address the occurrence of colorism in institutions, particularly in social institutions such as in the Indian arranged marriage market. The challenge will be for prospective aggrieved parties to prove such a claim in a court of law, given the inherent subjectivity of skin color. The law should address the inherent reason behind the existence of colorism, i.e. the desire for whiteness, rather than simply include color as a ground of discrimination. It is only when colorism is addressed in this holistic sense, encompassing discrimination in the social settings in which it is embedded, can the problem of colorism be resolved. The law must enable victims of colorism to establish claims of discrimination. Merely including "color" as a ground of discrimination in Article 15 of the Constitution of India will not be sufficient to enable such claims. To succeed, claimants will need to rely on the limited jurisprudence of Article 15 and the largesse of the court for success. A statute that addresses the complexities of colorism and its manifestation in society will be more successful in uprooting colorism.

A law on colorism must consider the issue of skin color discrimination in India more comprehensively rather than through the generic provisions of Article 15. In framing a law on colorism, India should look to the American experience under Title VII of the Civil Rights Act of $1964 .{ }^{193}$ For instance, United States courts have ruled that people bringing color-based claims must also be a member of a group that has been discriminated against in American history. ${ }^{194}$ Accordingly, a person of Pakistani origin was not allowed to bring such a claim. ${ }^{195}$ It is interesting to note that, in the United Sates, a majority of the colorism claims have been brought by South Asians. ${ }^{196}$ Does this mean that there is more colorist prejudice against South Asians, or is it that South Asians are more conscious of colorism? Angela Harris states that the United States government actively regulates race but only passively regulates color. ${ }^{197}$ Few claims have been brought in American courts solely on the ground of color. More often, claims of colorism are conflated with race or national origin. ${ }^{198}$ The reason for this may be that colorism still needs to establish itself as a legitimate and sufficient ground of discrimination.

Another interesting point to note from the American experience is that, contrary to expectations, not all plaintiffs bringing claims are dark-skinned. Some claims have been brought by light-skinned plaintiffs alleging discrimination towards them by dark-skinned people. 199 The reasons for this kind of retaliatory action can be an interesting point for future research. Further, it will be interesting to see if such cases already exist in India, and if so, whether a law on colorism will bring them to light. Indian legislators should keep in mind that Title VII solely addresses employment discrimination claims,

193 “Title VII's protections against color discrimination prohibit an employer from making detrimental employment decisions based on the immutable characteristics of color.” Nance, supra note 30, at 460.

194 Nance, supra note 30, at 459-60.

195 "The court recognized that 'the literal language of the statute which prohibits discrimination on the basis of “color" would seem to apply to Ali's claim,' but stated that 'the testimony regarding skin color variations among the peoples of Pakistan does not suffice to merit the division of Pakistanis into distinct "protected classes" according to color." Id. at 458-59.

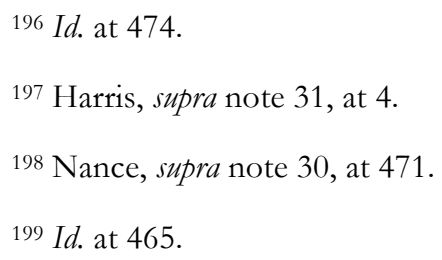


whereas a similarly confined law in India will cover only a small proportion of existing instances of colorism.

It is unlikely that a court in the United States will allow colorism claims brought by Indians against each other. An American court has previously rejected a colorism claim brought by a Pakistani against a fellow countryman. ${ }^{200}$ The court seemed reluctant to uphold the existence of colorism based on the testimony regarding skin color variations in Pakistan. ${ }^{201}$ Indian courts may find it equally hard based on the history of colorism in India detailed previously in this paper to justify the division of Indians into "protected classes" based on color. ${ }^{202}$ This may be because there is no direct evidence in Indian or Pakistani history that may suggest the consistent subjugation of a particular group by another over time, based on color.

\section{CONCLUSION}

This Article finds that colorism is manifested in complex forms in society and that the existing economic theories of racism are unable to rationalize it. The only theory that is able to explain the desire for whiteness is the theory of status production. ${ }^{203}$ However, the constraints in the construction of this theory restrain its ability to satisfactorily explain colorism. While status creation may be an objective of colorism, the theory does not satisfactorily explain how status production, in the manner described by McAdams, may be the means to that end. The idea of status as an end result of racism and colorism is compelling and resonates globally. Thus, it is worth exploring whether other means of status production would achieve the same result. Perhaps this theory could draw upon the more universal history of colonial domination outlined in this paper, rather than that of the Jim Crow South, for its explanation of racism. Nevertheless, the theory of status production may be most useful to us in understanding colorism, particularly because it makes a strong argument for considering colorism as a by-product of racism.

The primary distinction between colorism and racism is that unlike colorism, skin color is not the sole basis for discriminatory classifications in racism. This distinction is the chief reason for the inability of the theories of racism to explain colorism. Interestingly, however, the theory of statistical discrimination provides a neat explanation of colorism in the Indian arranged marriage market. This is probably because distinctions are made in India based solely on minute differences in skin tone. Consequently, discrimination occurs according to a gradient that follows complexion differences. Membership of a group may not be significant for discrimination to be statistically induced in such a situation.

By comparing colorism in the United States and India, this Article produces a universal account of colorism. It establishes the domination of skin color in discriminatory decision making. Regardless of its form, the role of racism in constituting colorism cannot be overlooked. In the United States, color is often not the sole basis for discrimination. Two questions emerge that may warrant further study. In comparison, can colorism be more widespread in India? What explains the persistence of colorism in India's predominantly racially homogenous society?

\footnotetext{
${ }^{200}$ Id. at 458-59 (citing Ali v. Nat'l Bank of Pakistan, 508 F. Supp. 611 (S.D.N.Y. 1981)).

201 Id. at 458 .

${ }^{202}$ Id. at 458-59.

203 See generally McAdams, supra note 8.
} 